\title{
Seabird feeding on benthic amphipods facilitated by gray whale activity in the northern Bering Sea
}

\author{
Jacqueline M. Grebmeier ${ }^{1}$, Nancy M. Harrison ${ }^{2}$ \\ 'Graduate Program in Ecology, The University of Tennessee, Knoxville, Tennessee 37996, USA \\ ${ }^{2}$ Royal Society for the Protection of Birds, The Lodge, Sandy, Bedfordshire SG19 2DL, United Kingdom
}

\begin{abstract}
Ampeliscid amphipods are the dominant benthic fauna in the northern Bering Sea and the major food of the California gray whale. Field studies indicate that benthic amphipods brought to the surface during gray whale feeding provide a food source for surface-feeding birds (northern fulmars, red phalaropes, black-legged kittiwakes) as well as diving birds (thick-billed murres). A sampling grid was used to document zooplankton and benthic population structure. Neuston tows, behavioral observations and collections of birds for stomach content analyses were made within and outside of 'whale slicks', the muddy plumes at the sea surface marking a site where a feeding whale has surfaced. Results indicate that infaunal amphipods are abundant at the surface in whale slicks, and that abundance and size-class of these floating amphipods directly reflect relative abundance and size-class of the major amphipod species found in the underlying benthos. Surface-feeding birds ate mostly small amphipods at the slicks, which were the dominant amphipod size-class observed in the tows. Birds as divergent in size as northern fulmars $(700 \mathrm{~g})$ and red phalaropes $(60 \mathrm{~g})$ consumed small amphipods or fragments less than $2 \mathrm{~mm}$ in length. Thick-billed murres, which dive to feed, caught the larger amphipods that sank. Location and abundance of northern fulmars and red phalaropes feeding in the study area were positively related to occurrence of feeding whales. The breeding thick-billed murres and black-legged kittiwakes were in a more restricted distribution on the east side of the grid, nearest the seabird colonies on King Island, Alaska, USA. The local distribution of all 4 species is shaped by whale feeding activity, and their diet is a direct reflection of benthic population structure of the northern Bering Sea.
\end{abstract}

\section{INTRODUCTION}

The northern Bering Sea is a major feeding area for the benthic-grazing California gray whale Eschrichtius robustus. The area south of Bering Strait and north of St. Lawrence Island, Alaska, USA (the Chirikov Basin) is a physically-dynamic, highly productive, shallow continental shelf where pelagic-benthic coupling is important in maintaining high populations of both benthic fauna as well as marine mammals and birds (Walsh et al. 1989, Grebmeier \& Barry 1991). The benthic fauna is dominated by ampeliscid (Ampelisca and Byblis), isaeid (Protomedia), lysianasscid (Anonyx) and aorid (Lembos) amphipods (Stoker 1981, Grebmeier et al. 1989), which are also the major food of the gray whale (Oliver et al. 1983, Nerini 1984). These amphipods occur in very high densities, with values ranging from 3000 to 14000 individuals (ind.) per $\mathrm{m}^{2}$, and occupy fine sand and silt/clay sediments located north of St. Lawrence Island (Stoker 1981, Nerini 1984,
Grebmeier et al. 1989); a recent study by Highsmith \& Coyle (1990) showed that this is one of the most productive benthic amphipod communities in the world.

In the process of feeding, gray whales gouge out troughs in the sea bottom and suspend sediment and debris, as well as small and fragmented amphipods, leaving murky plumes at the surface. This feeding may have an important influence on benthic community structure (Nelson \& Johnson 1987, Grebmeier et al 1989), and possibly on the pelagic community through turning over nutrients from the bottom to surface waters. Seabirds have been repeatedly observed feeding in association with whales (Harrison 1979, Obst \& Hunt 1990). The purpose of our study was to investigate the association of seabirds with whales and to consider how they are beneficiaries of the productive benthic community.

Gray whales feed at the bottom by suction, removing a swath of the bottom sediment and filtering it through 
short baleen plates, retaining larger ampeliscid amphipods (Oliver et al. 1984). The cumulative impact of the whales is immense; Johnson \& Nelson (1984) estimate that gray whales in the region suspend $1.2 \times 10^{9} \mathrm{~m}^{3}$ $\mathrm{yr}^{-1}$ of sediment, or twice the annual sediment input of the nearby Yukon River. Recent studies of the benthic community established distinct spatial patterns across the Chirikov Basin in the overall biomass and size distribution of infaunal amphipods, due to a combination of variable food supply to the benthos and sediment heterogeneity (Grebmeier et al. 1989, Grebmeier unpubl.). Amphipods average $85 \%$ of the total benthic faunal abundance in this area. In particular, ampeliscid amphipods (Ampelisca and Byblis) comprise $70 \%$ of all benthic fauna, with isaeid amphipods (Protomedia) being the second dominant fauna (11\%; Grebmeier et al. 1989).

In a separate study in 1985 and 1986, the association of 4 seabird species with feeding whales was investigated (Obst \& Hunt 1990). The dominant seabirds (Harrison 1987) were northern fulmar Fulmarus glacialis, red phalarope Phalaropus fulicara, black-legged kittiwake Rissa tridactyla, and thick-billed murre Uria lomvia. Other bird species were also seen with the whales in lower numbers (Obst \& Hunt 1990). This study suggested that these bird-whale slick associations may be very important for the seabirds, both dominating their foraging time and potentially determining their local distribution. In the present study we had 3 objectives: (1) to investigate the surface slicks using plankton nets to determine what prey are available for the birds, (2) to compare food samples retrieved from the 4 seabird species to investigate whether there were any divergences in their use of prey at the whale slicks, and (3) to examine whether the small-scale distribution of the seabirds reflected the abundance of amphipods or their size distribution in the benthos.

\section{METHODS}

Three latitudinal transects were investigated in 1985 and 1986 between King Island and the international dateline at the border between the Russian Republic and the USA in the northern Bering Sea (Fig. 1). These transects are designated as King Island North (KIN, latitude $65^{\circ} 12^{\prime} \mathrm{N}$ ), King Island-Dateline (KID, latitude $65^{\circ} 04^{\prime} \mathrm{N}$ ), and King Island South (KIS, latitude $64^{\circ} 50^{\prime} \mathrm{N}$ ); in 1985 most work was along the KID transect, in 1986 work was conducted on all 3 transects. In 1985 field work was completed in July and August (26 July to 12 August), which was marked by calm weather and observations of many whales feeding with associated birds. Due to ship scheduling, we did not reoccupy the sites in the northern Bering Sea until August 1986

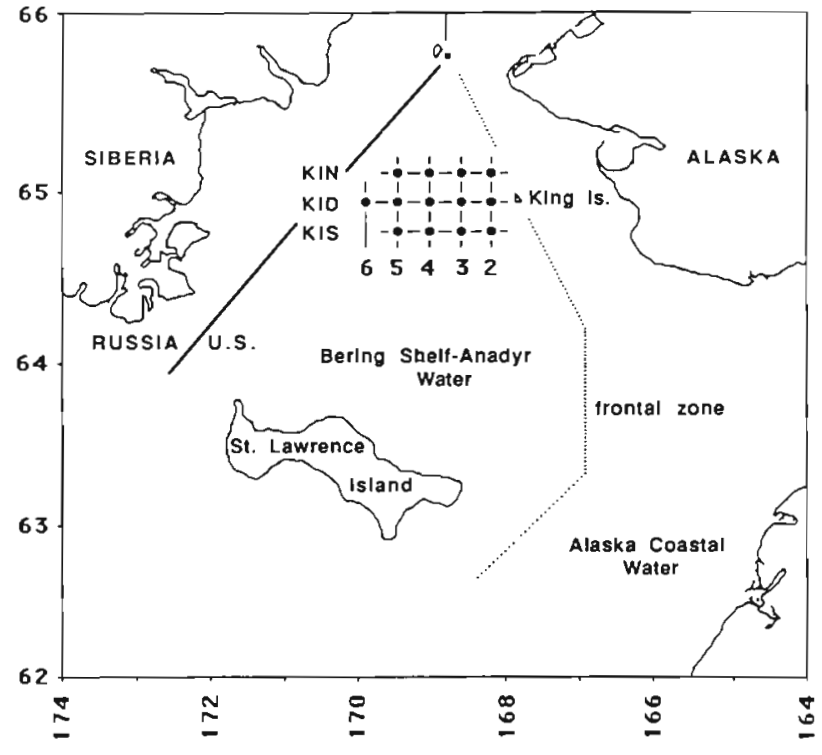

Fig. 1. Position of sampling grid in the northern Bering Sea

(10 to 26 August), when both the number of feeding whales were down and deteriorating weather limited our study. Bird surveys and collections were made along the transects in conjunction with Dr George Hunt, Jr, University of California, Irvine (Obst \& Hunt 1990). Neuston and benthic sampling were conducted at 12 stations along the transects as well as at sites of whale slicks in the area.

Neuston tows, using a $0.45 \mathrm{~mm}$ Samiota mesh net in 1985 and a $0.505 \mathrm{~mm}$ mesh net on a $1 \mathrm{~m}$ ring in 1986 . were used to collect material in the surface water, both within whale slicks (experimental sites) and outside slicks (control sites). Samples were washed into the cod end of the net and preserved in $5 \%$ formalin. Fauna were keyed to genera and separated into the following size-classes: $2-5 \mathrm{~mm}, 5-10 \mathrm{~mm}, 10-20 \mathrm{~mm}$ and $>20 \mathrm{~mm}$. Counts were made of each size-class within genera. Determining the density of neuston in the whale slicks was not possible due to dilution effects when the slick was overshot during tows

Benthic fauna were sampled by collecting 4 replicate $0.1 \mathrm{~m}^{2}$ van Veen grabs (with penetration enhanced by $32 \mathrm{~kg}$ lead weights) at each station. Each sample was washed through $1 \mathrm{~mm}$ screens and specimens subsequently preserved in $10 \%$ hexamethyltetraminebuffered formalin, stored in plastic Whirl-pak ${ }^{\mathrm{TM}}$ bags, and saved for laboratory analysis. Amphipods were separated from the other fauna and keyed to genera and separated into the designated size-classes described for the neuston. Counts were made of each sizeclass in the dominant genera. A ratio was determined for the number of Ampelisca and Byblis amphipods 
collected in the benthic samples, an indicator of the relative abundance of the dominant 2 amphipods collected in the study. For example, an Ampelisca/Byblis (A/B) ratio of 1 describes a population containing equal numbers of both genera of amphipods. An $A / B$ ratio $<1$ indicates a larger proportion of Byblis amphipods in the sample, whereas an $A / B$ ratio $>1$ indicates a larger proportion of Ampelisca amphipods in the sample.

Bird diet was determined for 4 species of seabirds collected in the immediate vicinity of whale slicks where neuston tows were made. A representative sample (7) of each bird species was collected in 1985 under license using a 12-gauge shot gun; no birds were collected in 1986. Stomachs and crops were removed and stored in $80 \%$ ethanol for later content determination. The procedure for size-class determination and abundance outlined above for neuston samples was followed in the laboratory for stomach samples as well.

Comparisons between species were made using a dietary overlap index adapted from Horn (1966):

$$
\text { Overlap }=\frac{2 \sum_{i=1}^{s} x_{i} y_{i}}{\sum_{i=1}^{s} x_{i}{ }^{2}+\sum_{i=1}^{s} y_{i}{ }^{2}}
$$

where $s=$ number of prey categories in the 2 bird species being compared and category $i$ is represented $x$ times in species $x$ and $y$ times in species $y$. Overlap values range from ' 0 ' for no overlap to ' 1 ' representing total overlap. Comparisons were made using this index of both the prey type consumed by the birds and the prey size consumed.

Observations of birds and whales were made as we were in transit along the transects between stations. Whales and whale-associated birds were counted during a general survey of the birds, and have been reported separately (Obst \& Hunt 1990).

\section{RESULTS}

\section{Neuston composition, abundance and size-class}

Neuston tows indicated that large numbers of small and fragmented benthic amphipods were floating at the surface in areas of whale activity. All neuston tows from whale slicks contained benthic amphipods, or smaller amphipod fragments (Table 1); broken legs were the most abundant material in the tows. Although infaunal benthic amphipods were generally not present in samples collected away from feeding whales (controls), 2 of the 5 control samples contained low densities of amphipod legs, indicating the extent whale activity affects the general area. Presumably these amphipod legs would not inhabit the surface waters unless brought to the surface through whale feeding activity. Ampelisca and Protomedia amphipods were the most commonly observed genera in the neuston tows for all transects in 1985 (Table 1). Byblis amphipods were most numerous in tows from the

Table 1. Percent $(\geq 50$ ) of neuston samples (sample size) containing benthic amphipods and other plankton for both whale feeding and control sites in 1985 and 1986. Transects: KID: King Island-Dateline; KIS: King Island South; KIN: King Island North

\begin{tabular}{|c|c|c|c|c|c|}
\hline \multirow[t]{3}{*}{ Prey } & \multicolumn{2}{|c|}{1985} & \multicolumn{3}{|c|}{1986} \\
\hline & \multirow{2}{*}{$\begin{array}{l}\text { Whale slick } \\
\text { KID }(10)\end{array}$} & \multirow{2}{*}{$\begin{array}{l}\text { Control } \\
\text { KID (5) }\end{array}$} & \multicolumn{2}{|c|}{ Whale slick } & \multirow{2}{*}{$\begin{array}{c}\text { Control } \\
\text { KID, KIN, KIS (5) }\end{array}$} \\
\hline & & & $\operatorname{KIS}(7)$ & $\operatorname{KIN}(4)$ & \\
\hline \multicolumn{6}{|l|}{ Benthic amphipods } \\
\hline Amphipod legs & 100 & - & 100 & 100 & - \\
\hline Ampelisca & 100 & - & 71 & 100 & - \\
\hline Protomedia & 90 & - & 100 & 100 & - \\
\hline Lysianassidae & 50 & - & - & - & - \\
\hline Pleustidae & - & - & 71 & - & - \\
\hline Photis & - & - & - & 50 & - \\
\hline Byblis & - & - & 100 & - & - \\
\hline \multicolumn{6}{|l|}{ Plankton } \\
\hline Neocalanus plumchrus & 100 & - & 71 & 75 & - \\
\hline Hippolytidae larvae & 100 & - & - & - & - \\
\hline Tanaids & 90 & - & 57 & 75 & - \\
\hline Pseudocalanus elongatus & 80 & - & 100 & 100 & 100 \\
\hline Pteropods & 80 & - & - & - & 80 \\
\hline Brachyuran crab larvae & 70 & 60 & - & - & 60 \\
\hline Chaetognaths & - & - & - & - & 80 \\
\hline Eucalanus bungii & - & - & 100 & 100 & 100 \\
\hline Calanus marshallae & - & - & - & - & 60 \\
\hline Hyperiid amphipods & - & - & 71 & 75 & - \\
\hline
\end{tabular}


southern KIS transect in 1986. A variety of other amphipods occurred in much lower frequencies, although the majority of fragments in the neuston were not easily identified and are listed as 'amphipod legs'.

Other plankton not typical of the neuston were also found in the whale slicks (Table 1). Large calanoid copepods (Neocalanus plumchrus) and hippolytid larvae occurred in $100 \%$ of the neuston tows at whale slick sites, while absent from tows at control sites. Tanaids, small copepods (Pseudocalanus elongatus) and pteropods were also dominant plankton within whales slicks in 1985 and 1986. Although they sometimes occurred in control sites away from whale slicks. their abundance dropped off significantly. Any differences in plankton composition in the neuston between 1985 and 1986 would also include seasonal plankton community changes.

\section{Benthic amphipod composition, abundance and size-class}

The size-classes and abundance of both Ampelisca and Byblis amphipods in the study area are presented in Table 2. Average abundance of these 2 dominant amphipod genera ranged from 1985 to 7454 ind. $\mathrm{m}^{-2}$ over the study area. The $A / B$ ratio was used as an indicator of relative faunal composition of these 2 amphipod genera: Ampelisca (A) and Byblis (B). A high A/B ratio indicates areas of high abundance of Ampelisca amphipods relative to Byblis amphipods. Low $\mathrm{A} / \mathrm{B}$ values indicate areas of low to equal Ampelisca abundance relative to Byblis. Three stations were occupied during a preliminary study in 1985 along the KID transect for determination of amphipod size-classes (Stns KID2, KID4 and KID6; Figs. 1 \& 2). Ampelisca was

Table 2. Size-class and abundance (ind. $\mathrm{m}^{-2}$ ) of major amphipod genera, Ampelisca (A) and Byblis (B), at benthic stations in the northern Bering Sea during 1985 and 1986

\begin{tabular}{|c|c|c|c|c|c|c|c|c|c|c|}
\hline \multirow[t]{2}{*}{ Size-class $(\mathrm{mm})$} & \multicolumn{2}{|c|}{ Stn 6} & \multicolumn{2}{|c|}{ Stn 5} & \multicolumn{2}{|c|}{$\operatorname{Stn} 4$} & \multicolumn{2}{|c|}{$\operatorname{stn} 3$} & \multicolumn{2}{|c|}{ Stn 2} \\
\hline & A & $\mathrm{B}$ & A & $B$ & $A$ & B & A & $\mathrm{B}$ & A & B \\
\hline \multicolumn{11}{|c|}{ Transect KIN (1986) } \\
\hline $2-5$ & - & - & 483 & 393 & 1293 & 1008 & 688 & 723 & 183 & 53 \\
\hline $5-10$ & - & - & 448 & 283 & 1088 & 688 & 1978 & 240 & 593 & 40 \\
\hline $10-20$ & - & - & 830 & 473 & 595 & 180 & 645 & 65 & 738 & 25 \\
\hline$>20$ & - & - & 198 & 68 & 315 & 13 & 260 & 0 & 353 & 0 \\
\hline Total & - & - & 1959 & 1217 & 3291 & 1889 & 3571 & 1028 & 1867 & 118 \\
\hline Station total & \multicolumn{2}{|c|}{-} & \multicolumn{2}{|c|}{3176} & \multicolumn{2}{|c|}{5180} & \multicolumn{2}{|c|}{4599} & \multicolumn{2}{|c|}{1985} \\
\hline $\mathrm{A} / \mathrm{B}$ & \multicolumn{2}{|c|}{-} & \multicolumn{2}{|c|}{1.6} & \multicolumn{2}{|c|}{1.7} & \multicolumn{2}{|c|}{3.5} & \multicolumn{2}{|c|}{15.8} \\
\hline \multicolumn{11}{|c|}{ Transect KID (1985) } \\
\hline $2-5$ & 1110 & 663 & - & - & 925 & 1080 & - & - & 1235 & 213 \\
\hline $5-10$ & 1155 & 268 & - & - & 1455 & 763 & - & - & 1270 & 85 \\
\hline $10-20$ & 930 & 108 & - & - & 1228 & 225 & - & - & 995 & 20 \\
\hline$>20$ & 235 & 10 & - & - & 153 & 25 & - & - & 210 & 10 \\
\hline Total & 3430 & 1049 & - & - & 3761 & 2093 & - & - & 3710 & 328 \\
\hline Station total & \multicolumn{2}{|c|}{4479} & \multirow{2}{*}{\multicolumn{2}{|c|}{ - }} & \multicolumn{2}{|c|}{5854} & \multicolumn{2}{|c|}{ - } & \multicolumn{2}{|c|}{4038} \\
\hline$A / B$ & \multicolumn{2}{|c|}{3.3} & & & \multicolumn{2}{|c|}{1.8} & \multicolumn{2}{|c|}{-} & \multicolumn{2}{|c|}{11.3} \\
\hline Transect KID & & & & & & & & & & \\
\hline $2-5$ & - & - & 618 & 318 & 1360 & 1800 & 660 & 195 & 365 & 55 \\
\hline $5-10$ & - & - & 783 & 80 & 1403 & 1087 & 1338 & 150 & 1008 & 63 \\
\hline $10-20$ & - & - & 318 & 80 & 1270 & 207 & 823 & 43 & 323 & 23 \\
\hline$>20$ & - & - & 308 & 25 & 280 & 47 & 270 & 5 & 183 & 0 \\
\hline Total & - & - & 2027 & 503 & 4313 & 3144 & 3091 & 3393 & 1879 & 141 \\
\hline Station total & & - & & & & & & & & \\
\hline$A / B$ & & - & & & & & & & & \\
\hline Transect KIS 19 & & & & & & & & & & \\
\hline $2-5$ & - & - & 743 & 133 & 773 & 420 & 1005 & 400 & 1433 & 573 \\
\hline $5-10$ & - & - & 2028 & 160 & 1278 & 238 & 1280 & 218 & 1470 & 180 \\
\hline $10-20$ & - & - & 1525 & 88 & 760 & 55 & 628 & 158 & 673 & 73 \\
\hline$>20$ & - & - & 505 & 13 & 233 & 0 & 195 & 20 & 158 & 3 \\
\hline Total & - & - & 4801 & 394 & 3043 & 716 & 3108 & 796 & 3734 & 829 \\
\hline Station total & & - & & & & & & & & \\
\hline $\mathrm{A} / \mathrm{B}$ & & - & & & & & & & & \\
\hline
\end{tabular}




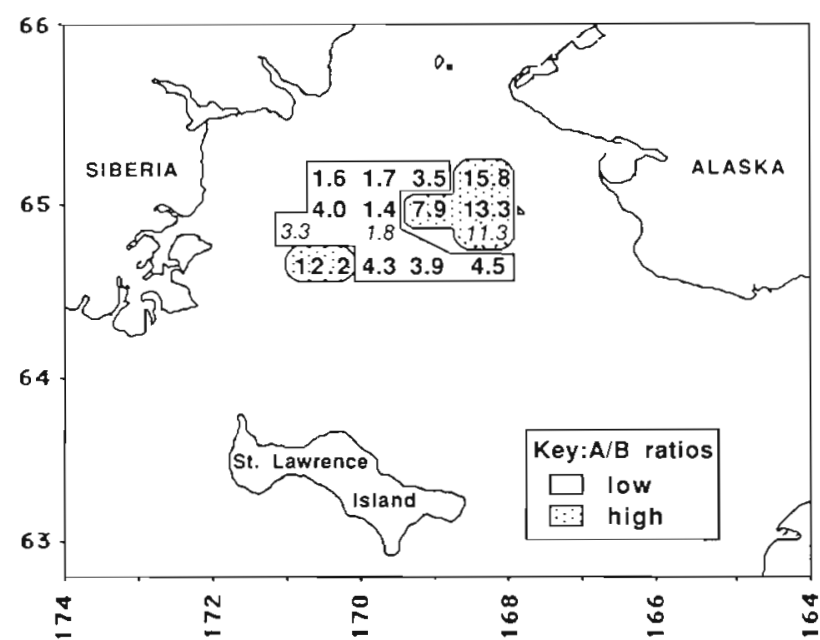

Fig. 2. Ampelisca/Byblis (A/B) ratios of benthic amphipods over the sampling grid in 1986 (numbers in bold). A/B ratios for stations occupied on the KID transect in 1985 are shown in italics below the $1986 \mathrm{KID}$ transect; these samples were collected at Stns KID2, KID4 and KID6, as presented in Fig. 1

the dominant ampeliscid amphipod in the east, indicated by the $\mathrm{A} / \mathrm{B}$ ratio of 11.3 , with Byblis increasing in abundance towards the western sector, indicated by low A/B ratios (1.8 to 3.3; Fig. 2). In 1986, 12 benthic stations were occupied on the grid (Fig. 2), with 2 of these stations (KID2, KID4) being re-occupations on the 1985 KID transect. The KIN transect (1986) had a similar trend in amphipod composition as the KID transect; $A / B$ ratios were highest in the east and lowest toward the west (Fig. 2). The southern transect in the study area (KIS) showed a reverse trend, with $\mathrm{A} / \mathrm{B}$ values relatively low and constant in the east and middle regions, indicating an abundance of Byblis, rising to a high value in the western region, indicating a higher number of Ampelisca amphipods. The A/B ratio is thus indicative of changing community structure; across the area species composition and size-class composition vary.

\section{Seabird feeding}

The 4 species of seabird most commonly seen at whale slicks were found to be eating infaunal amphipods (Table 3 ). Three of the species are restricted to feeding at the surface: red phalarope, black-legged kittiwake and northern fulmar. The stomachs of these 3 species had material similar to that collected in neuston tows, with stomach contents dominated by Ampelisca, Byblis and Protomedia amphipods (Table 1). In addition, despite the fact that these 3 bird species had vastly different body sizes and bill dimensions, they had selected prey of a similar size.

The measure of dietary overlap indicates high similarity between the 3 surface-feeding species in the prey taken, both the taxa of the prey (Table 4A) and the size of food particles (Table 4B) consumed. Values near 1 indicate nearly identical prey taken; of the prey taxa taken by the surface feeding species, 4 dominated: Ampelisca, Byblis, Protomedia and Anonyx (Table 3). The thick-billed murre contained a number of other crustacean taxa (e.g. Pontoporeia, Lembos, and crangonid shrimp) absent from the other seabird species. In particular, large Lembos and Anonyx amphipods were more frequently eaten by thick-billed murres than the other seabird species, hence the much lower index of similarity (Table 4A).

Table 3. Percent of collected birds with prey in 1985 (sample of 7 individual birds for each species)

\begin{tabular}{|c|c|c|c|c|}
\hline Prey & $\begin{array}{c}\text { Red } \\
\text { phalarope }\end{array}$ & $\begin{array}{l}\text { Black-legged } \\
\text { kittiwake }\end{array}$ & $\begin{array}{l}\text { Northern } \\
\text { fulmar }\end{array}$ & $\begin{array}{c}\text { Thick-billed } \\
\text { murre }\end{array}$ \\
\hline \multicolumn{5}{|l|}{ Benthic amphipods } \\
\hline Ampelisca & 71 & 100 & 100 & 57 \\
\hline Byblis & 71 & 14 & 100 & 57 \\
\hline Protomedia & 14 & 29 & 71 & 0 \\
\hline Anonyx & 14 & 14 & 43 & 71 \\
\hline Other Lysianassidae & 14 & 0 & 0 & 0 \\
\hline Photis & 0 & 14 & 14 & 0 \\
\hline Lembos & 0 & 0 & 0 & 86 \\
\hline Pontoporia & 0 & 0 & 0 & 14 \\
\hline Pleustidae & 0 & 0 & 14 & 0 \\
\hline \multicolumn{5}{|l|}{ Plankton } \\
\hline Tanaidae & 0 & 0 & 57 & 0 \\
\hline Hippolytidae & 0 & 0 & 0 & 29 \\
\hline Crangonidae & 0 & 0 & 0 & 29 \\
\hline Neocalanus plumchrus & 0 & 0 & 14 & 0 \\
\hline Scyphomedusae & 0 & 43 & 29 & 29 \\
\hline
\end{tabular}


Table 4. Matrix of overlap indices describing similarities in prey type and prey size eaten by seabird species

\begin{tabular}{|c|c|c|c|}
\hline & $\begin{array}{l}\text { Northern } \\
\text { fulmar }\end{array}$ & $\begin{array}{c}\text { Black-legged } \\
\text { kittiwake }\end{array}$ & $\begin{array}{c}\text { Thick-billed } \\
\text { murre }\end{array}$ \\
\hline \multicolumn{4}{|c|}{ A. Similarities in prey type } \\
\hline Red phalarope & 0.79 & 0.73 & 0.63 \\
\hline Northern fulmar & - & 0.69 & 0.60 \\
\hline $\begin{array}{l}\text { Black-legged } \\
\text { kittiwake }\end{array}$ & - & - & 0.47 \\
\hline \multicolumn{4}{|c|}{ B. Similarities in prey size } \\
\hline Red phâlarope & 0.81 & 0.75 & 0.05 \\
\hline Northern fulmar & - & 0.85 & 0.28 \\
\hline $\begin{array}{l}\text { Black-legged } \\
\text { kittiwake }\end{array}$ & - & - & 0.23 \\
\hline
\end{tabular}

Dietary overlap calculated for prey size also indicated high similarity between the surface-feeding species, and particularly low overlap between these 3 species and thick-billed murres (Table 4B). The greatest division in the samples was by prey size, with thickbilled murres taking distinctly larger prey. The 3 surface-feeding species consumed virtually identical sizes and taxa of prey. Their diets were dominated by the small size-categories of Ampelisca and Byblis which were so abundant in the neuston and benthos (Table 5).

Small size-classes of amphipods dominated neuston tows and bird stomachs (Table 5). Neuston tows collected in whale slicks contained a high percentage of the smaller size-classes of amphipods that floated, and this was mirrored in the stomach contents of the surface-feeding seabirds (Table 5). Although the larger amphipod size-classes (>10 mm) were absent from the neuston tows in whale slicks, $33 \%$ of the

Table 5. Size-class of amphipods in neuston samples, surface seabird collections, and benthic grabs ( $n$ = sample size)

\begin{tabular}{|c|c|c|c|c|}
\hline \multirow[t]{2}{*}{ Sample type } & \multicolumn{4}{|c|}{ Size-class of amphipods (mm) } \\
\hline & $2-5$ & $5-10$ & $10-20$ & $>20$ \\
\hline $\begin{array}{l}\% \text { Neuston tows at } \\
\text { whale slicks with } \\
\text { size-class present (n=10) }\end{array}$ & 100 & 80 & 0 & 0 \\
\hline $\begin{array}{l}\% \text { of total abundance } \\
\text { in neuston tows }(n=10)\end{array}$ & 71 & 29 & 0 & 0 \\
\hline $\begin{array}{l}\% \text { Surface-feeding } \\
\text { seabirds containing } \\
\text { size-class }(n=21)\end{array}$ & 76 & 52 & 33 & 5 \\
\hline \multicolumn{5}{|c|}{$\%$ Size-class (Ampelisca + Byblis) in benthos } \\
\hline July $1985(n=3)$ & 37 & 34 & 24 & 5 \\
\hline August $1986(n=12)$ & 31 & 38 & 23 & 8 \\
\hline
\end{tabular}

surface-feeding birds still contained at least 1 fragment in the 10-20 $\mathrm{mm}$ size-class, and $5 \%$ of the bird stomachs contained at least 1 fragment in the $>20 \mathrm{~mm}$ amphipod size-class. All 3 surface-feeding birds ate specific size categories of amphipod prey in similar proportion to their availability in the whale slicks (Table 5). These birds did not appear to be selective, although the northern fulmar was the only species feeding on the copepods in the neuston, with the phalaropes and kittiwakes feeding primarily on benthic amphipods (Table 3 ).

\section{Distribution of seabirds relative to whales and benthic community}

Black-legged kittiwakes, red phalaropes, northern fulmars and thick-billed murres were the dominant bird species observed feeding at gray whale slicks in 1985 (Obst \& Hunt 1990). The surface-feeding seabirds comprised 50 to $87 \%$ of the seabirds feeding with whales, with diving alcids making up about $15 \%$ of all the birds feeding at whale slicks. In 1985 gray whaies were most abundant in the western section of the Chirikov Basin, with only a few sightings in the eastern portion (Fig. 3). Northern fulmars and red phalaropes occurred at the western extreme of the transect and fed with these whales. In comparison, black-legged kittiwakes and thick-billed murres (both locally breeding species) were more abundant to the east near King Island.

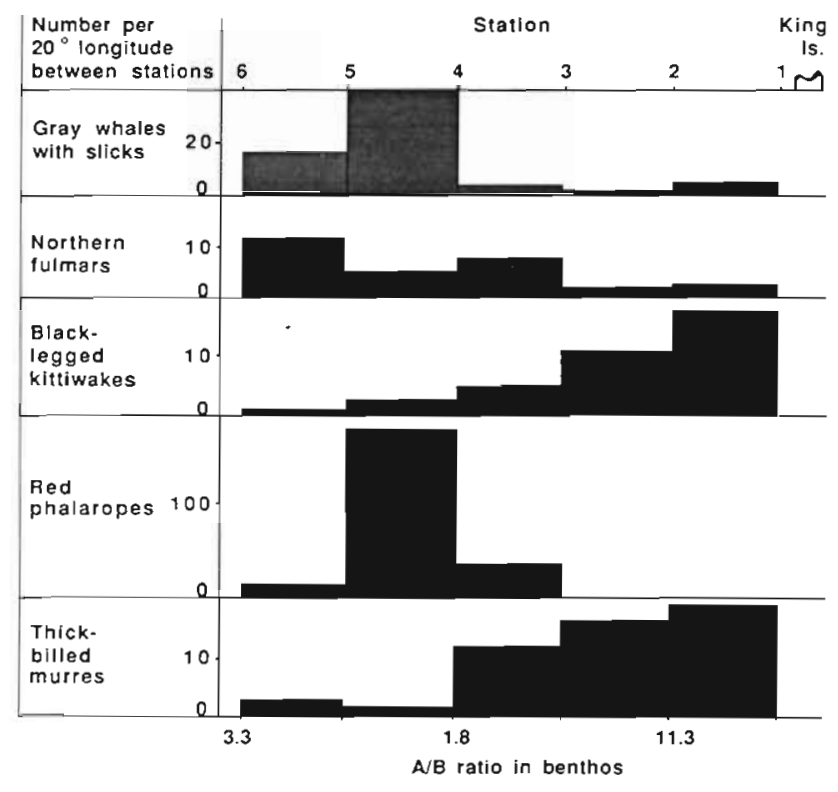

Fig. 3. Abundance of whales and seabirds along KID transect (26 July 1985) relative to $A / B$ ratios in the benthos 


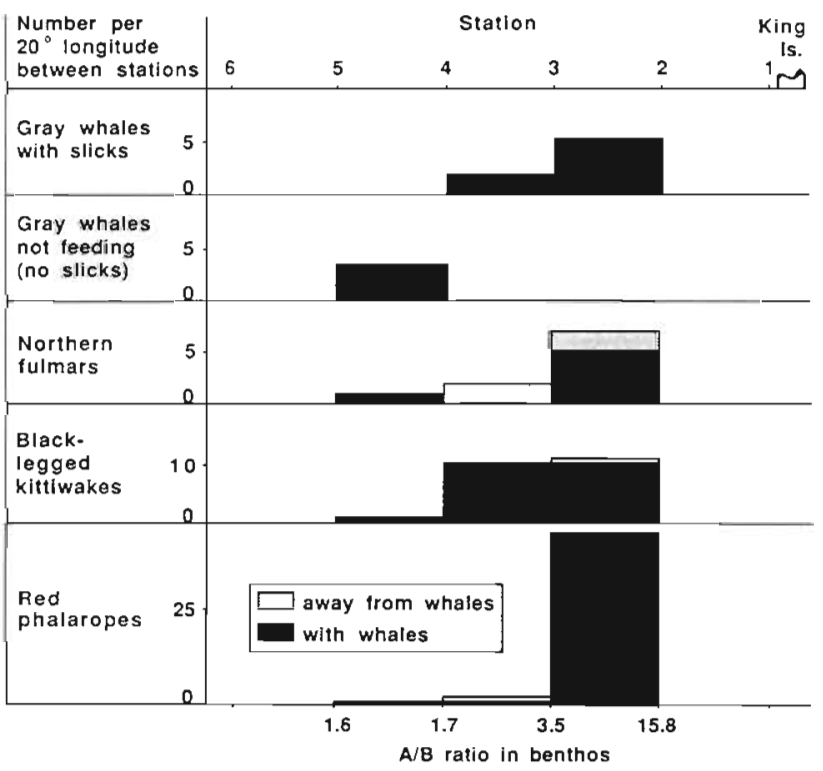

Fig. 4. Abundance of whales and seabirds along KIN transect (21 August 1986) relative to $A / B$ ratios in the benthos

Ampelisca and Byblis were consumed in the same frequency by northern fulmars, which were feeding farthest to the west side of the grid in 1985 (Table 3, Fig. 3). Similarly, they were consumed with the same frequency by red phalaropes, also feeding to the west; this corresponds to an area where there was a similar abundance of Ampelisca and Byblis in the sediments (low A/B ratio; Fig. 3). In contrast, the black-legged kittiwake, which is most abundant to the east where there is an Ampelisca-dominated community (high A/B ratio; Fig. 3), had a high frequency of Ampelisca and a low frequency of Byblis (Table 3). Thick-billed murres consumed a much wider variety of prey, only available to a sub-surface diver; the similar frequency of Ampelisca and Byblis is at variance with the above pattern.

Fewer whales were encountered in 1986 when the cruise occurred a month later than in 1985 (Fig, 4). The trend in the benthos, with low $\mathrm{A} / \mathrm{B}$ ratios in the amphipod community in the west and high $\mathrm{A} / \mathrm{B}$ ratios in the east, was once again apparent. However, during this field season, the highest abundance of gray whales and northern fulmars occurred in the eastern section of the study area, as did those of red phalaropes and black-legged kittiwakes. Once again, seabirds were more abundant in areas with whale slicks. In 1986 whales were encountered that were not actively feeding (no slicks) and the coincident counts of surfacefeeding bird abundance were extremely low (Fig. 4). In some areas slicks were encountered although no whales were in sight, and seabird abundance increased in these areas.

\section{DISCUSSION}

Associations between seabirds and marine mammals have been found to occur regularly, mostly as the result of their convergence on a concentration of prey (Evans 1982). There may be mutual benefits from marine mammal-bird associations, where one species is made aware of a prey patch by another's behavior. Birds frequently benefit from whale or seal feeding activity; many marine mammals are known to herd their prey as they feed, chasing schools of crustaceans or fish to the surface which would otherwise be too deep for birds to capture (Pierotti 1988). In our study, observations of seabirds feeding on amphipods made accessible by gray whale feeding is somewhat akin to terrestrial birds feeding in the track of large ungulates, catching insects flushed from the ground (Dean \& MacDonald 1981).

Our results indicate that surface-feeding birds are feeding opportunistically on small amphipods which are made abundant in the neuston by whale feeding activity. Small amphipods are likely to be abundant because they are lost through the baleen of the filterfeeding gray whales and remain suspended in the surface water for a longer period of time than larger sizeclasses. Prey availability to the birds therefore depends on the suspension of amphipods by whales, and the size and species composition of the benthic fauna. During feeding, whales introduce a representation of benthic species composition into the neuston, changing through time and space, dependent on the size composition of amphipods and their sinking rates. Our data indicate all seabird species were feeding opportunistically, with the prey taken by the birds dependent on whale activity and the underlying benthic community structure.

Red phalaropes and northern fulmars were all either non-breeding or post-breeding individuals and thus free to follow the whales throughout the study area. The closest fulmar colony is at St. Matthew Island $500 \mathrm{~km}$ to the south of our study area, and red phalaropes breed on the Arctic tundra and are likely to be staging for migration in these whale-feeding areas (Obst \& Hunt 1990). The high abundance of these 2 species at the western extreme of the transect in 1985 were coincident with heavy whale feeding. In 1986, whales were sited in the eastern sector of our sampling grid, and once again northern fulmars and red phalaropes were closely associated with whale slicks. These data indicate that these 2 species feed with the whales throughout the study area wherever the whales may be active.

The fulmars and phalaropes, all collected from the west side of the grid in 1985, were found to have a diet made up of very small amphipods, reflecting the benthic community structure in the area. In those areas 
where many very small amphipods dominated the infauna, whale slicks were persistent, with small suspended amphipods floating for long periods of time. The fact that the birds were found to have eaten some amphipod fragments larger than those found in the neuston suggests they quickly descended on a whale as it surfaced, picking up any big fragments first. However, both the fulmars and phalaropes, with 600 to $700 \mathrm{~g}$ difference in weight, would remain at whale slicks long periods, cleaning up thousands of tiny amphipod fragments (Obst \& Hunt 1990).

In contrast, birds breeding on King Island (blacklegged kittiwakes and thick-billed murres) are restrained by nesting requirements, and are thus closely tied to whale activity in the eastern side of the grid, nearest the island (20 miles away). The amphipods made available by the whales may be an important resource for birds breeding on King Island. Due to the restricted distribution of these particular seabirds, their prey (as made available by the whales) would reflect the underlying benthic amphipod community, which is dominated by the larger size-classes of Ampelisca species. Material in whale slicks in this area likely sink more rapidly, but the large size and abundance of amphipods suspended makes for the surprising association of large, pursuit-diving thick-billed murres with the whales. While the prey taken by the black-legged kittiwakes did not include larger amphipods, there were fewer Byblis represented in the stomachs, reflecting the underlying benthic community composition.

Additional seabird species, including least auklets Aethia pusilla, parakeet auklets Cyclorrhynchus psittacula, glaucous gulls Larus hyperboreus, horned puffins Fratercula corniculata and jaegers Stercorarius spp. have also been observed with gray whales (Harrison 1979, Obst \& Hunt 1990). Seabird-whale associations are likely to be important for many seabirds seasonally, depending on whale migration and seabird breeding restrictions. Harrison (1979) estimated the energy made available by feeding whales could support several hundred thousand seabirds. Given the high turnover rate of sediments in the northern Bering Sea by gray whale feeding activity reported by Johnson \& Nelson (1984), and our evidence of not only amphipod parts, but also increased mid-water plankton in whale slicks, the quantity of small crustacean prey made available by the large population of gray whales in the Bering Sea clearly forms a predictable and relatively rich energy source. We predict that areas with rich benthic amphipod life, such as that in the Chirikov Basin, will not only draw gray whales, but will consistently attract a diversity and abundance of gray whale associates. The extensive whale activity in the northern Bering Sea makes available a major source of food to the seabird community.
Acknowledgements. We thank the following people for assistance and cooperation in the field: G. Hunt, Z. Eppley, C. Williams, B. Obst, D. Veit and M. Whitehouse. C. Sullivan and D. Hammond provided laboratory space while J. Grebmeier was affiliated with the University of Southern California. We express appreciation to the Captain and crew of the RV 'Alpha Helix' for cooperation in the field and we thank 2 anonymous reviewers, along with $\mathrm{A}$. Springer and $\mathrm{L}$. Cooper, for making constructive comments on an earlier version of the manuscript. Financial support was provided by NSF grants DPP8308232, DPP84-05286 and DPP89-21955.

\section{LITERATURE CITED}

Dean, W. R. J., MacDonald, I. A. W. (1981). A review of African birds feeding in association with mammals. Ostrich 52: $135-155$

Evans, P. G. H. (1982). Associations between seabirds and cetaceans: a review. Mammal Rev. 12: 187-206

Grebmeier, J. M., Feder, H. M., McRoy, C. P. (1989). Pelagicbenthic coupling on the shelf of the northern Bering and Chukchi Seas. II. Benthic community structure. Mar. Ecol. Prog. Ser. 51: 253-268

Grebmeier, J. M., Barry, J. P. (1991). The influence of oceanographic processes on pelagic-benthic coupling in polar regions: a benthic perspective. J. mar. Syst. 2: 495-518

Harrison, C. S. (1979). The association of marine birds and feeding gray whales. Condor 81: 93-95

Harrison, N. M. (1987). Foraging behavior and coexistence of seabirds in the Bering Sea. Ph.D. dissertation, Univ. California, Irvine

Highsmith, R. C., Coyle, K. O. (1990). High productivity of northern Bering Sea amphipods. Nature, Lond. 344: $8662--8664$

Horn, H. S. (1966). Measurement of 'overlap' in comparative ecological studies. Am. Nat. 100: 419-424

Johnson, K. R., Nelson, C. H. (1984). Side-scan sonar assessment of gray whale feeding in the Bering Sea. Science 225: $1150-1152$

Nelson, C. H., Johnson, K. R. (1987). Whales and walruses as tillers of the sea floor. Scient. Am. 255: 112-117

Nerini, M (1984). A review of gray whale feeding ecology. In: Jones, M. L., Swartz, S. L., Leatherwood, S. (eds.) The gray whale Eschrichtjus robustus. Academic Press, New York, p. $423-463$

Obst, B. S., Hunt, Jr, G. L. (1990). Marine birds feed at gray whale mud plumes in the Bering Sea. The Auk: 107 $678-688$

Oliver, J. S., Slattery, P. N., Silberstein, M. A., O'Connor, E. F (1983). A comparison of gray whale, Eschrichtius robustus, feeding in the Bering Sea and Baja California. Fish. Bull. U.S. $81: 513-522$

Oliver, J. S., Slattery, P. N., Silberstein, M. A., O'Connor, E. F (1984). Gray whale feeding on dense amphipod communities near Branfield, British Columbia. Can. J. Zool. 62: 41-49

Pierotti, R. (1988). Associations between marine birds and mammals in the northwest Atlantic Ocean. In: Burger, J. (ed.) Seabirds and other marine vertebrates. Columbia University Press, New York, p. 31-58

Stoker, S. W. (1981). Benthic invertebrate macrofauna of the eastern Bering/Chukchi continental shelf. In: Hood, D. W. Calder, J. A. (eds.) The eastern Bering Sea shelf: oceanography and resources, Vol. 2. Univ. of Washington Press, Seattle, p. 1069-1090 
Walsh, J. J., McRoy, C. P., Coachman, L. K., Goering, J. J., Nihoul, J. J., Whitledge, T E., Blackburn, T H., Parker, P. L., Wirick, C. D., Shuert, P. G., Grebmeier, J. M., Springer, A. M., Tripp, R. D., Hansell, D., Djenidi, S., Deleersnijder, E., Henriksen, K., Lund, B. A., Andersen, P.,

This article was submitted to the editor
Muller-Karger, F. E., Dean, K. (1989). Carbon and nitrogen cycling within the Bering/Chukchi Seas: source regions for organic matter effecting AOU demands of the Arctic Ocean. Prog. Oceanogr. 22: 279-361

Manuscript first received: March 15, 1991

Revised version accepted: January 13, 1992 